\section{VP-45 前立腺精異全摘術の要点と対処}

\section{シータン泌尿器科外科 \\ ウン シータン}

前立腺癌に対する前立腺本体、精藿、前立腺尿道 Junction そして膀胱頝部の切除は色々な術式が発表されている。 特に最近内視鏡的な手術方法がさかんに行われている。 術者は1977年に Retropubic Radical Prostatovesiculectomyを発表してから今日に至って色々な改良方法を発 表した。2000年の総会に失禁防止膀胱尿道再吻合の Wedge-Shaped Anastomosis。そして2002 年の総会に Retropubic And Transperitoneal Combined Approach の術式を発表した。今回はこれらをまとめて前立腺癌に 対する手術の最も重要な点を次にあげて：1.きれいな視 野が得られること。2.切除したい組織を直視下で完全に 切除出来ること。3.患者に負担の少ない出血少量を得ら れること。4. 術後尿失禁と吻合部狭窄のないこと。以上 諸点に対する対処の Sketch 図説明が先行する術中 Videoをお見せしたい。

\section{VP-46根治的前立腺全摘術における陰茎海綿 体神経切除例に対する腓腹神経移植術}

\section{東北大学 医学部 泌尿器科学" 東北大学 医学部 形成外科学 ${ }^{2)}$}

德山 聡", 斎藤 誠一",斎藤 英郎", 中川 晴夫"

海法 康裕", 伊藤 明宏"

【目的】根治的前立腺全摘術に扮ける陰茎海綿体神経の温存 は、術後の勃起能の回復に非常に重要であり、両側、片㑡温存 の順に勃起能回復の成績が良いが、両側の陰茎海綿体神経を 切除せざるを得ない症例ではまず勃起能の回復が望めない。 1999 年 Kim らにより、両㑡陰茎海綿体神経の切除後、腓腹神 経移植術により勃起能の回復を認めた症例が初めて報告され た。当科でもこれまでに 2 例において腓腹神経移植術を施行 し、その外科的技術について記録したので報告する。【方法]無 結禁処理法により dorsal vein complex を切断した後、 lateral pelvic fascia を切除側の神経血管束 (NVB) の外㑡で頭側方向 に切開する。前立腺尖部一膜様部尿道の 5 時、7 時の部位で NVB を同定しておき、前立腺尖部から膜梯部尿道を切離す る。NVB の遠位側を、後に腓腹神経を吻合するのに十分な長 さを残してクリッブをかけ切断する。近位㑡は前立腺底部で NVBにクリップをかけ切断する。前立腺を摘出し膀胱䅡部を 形成後、片側の NVB 切除部の長さに相当する約 $5 \mathrm{~cm}$ の左腓 腹神経 (両㑡の場合は $10 \mathrm{~cm}$ ) を切離・収穫し、NVB 切除部に 逆向きに介在させ両断端を $7-0$ nylonにて 2 針ずつ神経上膜 にかけて吻合する。神経移植後、膀胱尿道吻合を行う。
VP-47前立眿全摘除術における尿道吻合法の 工夫一街後尿失禁予防のため

\section{名古屋市立東市民病院 泌尿器科}

上田 公介, 田貫 浩之, 成山泰道

目的：前立腺全摘除術における術後合併症として尿失禁 があげられる。今回はこれを予防する目的で、手術手技 に改良を用いた。対象と方法：対象は T2NOM0の前立腺 癌患者で、手術術式は恥骨後式前立腺全摘除術を用いた。 まず dorsal vein complex を処理した後、尿道を離断し、 尿道から前立腺と精变を摘出する。新内尿道口形成をお こない、尿道との吻合には Maniceps 鉗子を用いて 3 ヶ 所縫合するが、1ヶ所につき二重縫合とした。結果と考 察：尿道留置カテーテルは 10-14 日に抜去するが、この 方法を用いてからは術後の尿失禁はほとんどみられれな い。1 ケ所につき 2 重縫合とするため縫合糸がゆるまず、 確実に尿道吻合ができるため術後の尿失禁をきたさない ものと考えられる。

\section{VP-48 恥骨後式前立腺全摘における連続縫合 による膀胱尿道吻合法}

\section{大分医科大学 医学部 泌尿器科") 厚生連鶴見病院 \\ 三股 浩光”, 松原 孝典", 黑光 浩一", 野村 芳雄" \\ 中野大作 ${ }^{21}$}

緒言 われわれは留置カテーテルの早期抜去を目的として 正中脇索を切断し、腹膜を剥離して膀胱尿道吻合部に緊張が かからなくして 6 針結節縫合を行ってきたが、約 2 割に一過 性の尿閉が生じ、結節縫合では尿道粘膜が弁状にめくれて内 腔を閒塞するためと考えられた。今回われわれは連続縫合に よる膀胱尿道吻合を試みたのでビデオで供覧する。手技 1) 膀胱尿道吻合部に緊張がかからない上う膀胱底部より十分 に腹膜を剥離し、正中胼索を切断する。2) 尿道 6 時の部位は 直晹前面の組織を含めて深く $2-0$ vicryl で 1 針かけてお く。3) 2 本の 3-0 monocryl をまず膀胱䅡部 6 時の漿膜側に anchoring suture を行った後、外内に運針しておく。尿道㑡 は 6 時より時計方向に monocryl を内外に、膀胱䅡部は外内 に運針し、それぞれ 3〜4 回繰り返す。尿道側の 12 時の部位 で針系を出しておき、左側半分を終了する。4)右㑡半分は反 時計方向に運針し尿道側 12 時の部位に針系を出す。5）6 時に運針した vicryl を結紮する。6)䏽胱を尿道側に寄せなが ら2本の monocryl を毫引し、膀胱に生食を注入して漏れの ないことを確認してから結禁する。結論 本法は術後 1 週目 の留置カテーテル抜去が可能で、吻合部の尿漏れや一過性の 尿閉を防止できる手技と思われる。 